Boise State University

ScholarWorks

Political Science Faculty Publications and

Presentations

$5-2020$

\title{
Outside the Wire: U.S. Military Deployments and Public Opinion in Host States
}

Michael A. Allen

Boise State University

Michael E. Flynn

Kansas State University

Carla Martinez Machain

Kansas State University

Andrew Stravers

RAND Corporation 


\section{Outside the wire: U.S. military deployments and public opinion in host states*}

\author{
Michael A. Allen ${ }^{\dagger}$ \\ Department of Political Science \\ Boise State University \\ Carla Martinez Machain ${ }^{\S}$ \\ Department of Political Science \\ Kansas State University
}

\author{
Michael E. Flynn $\ddagger$ \\ Department of Political Science \\ Kansas State University \\ Andrew Stravers \\ Defense and Political Sciences \\ RAND Corporation
}

\footnotetext{
*This material is based upon work supported by, or in part by, the Minerva Research Initiative, U.S. Army Research Laboratory, and the U.S. Army Research Office under grant number W911NF-18-1-0087. Opinions and interpretations are those of the author and not the U.S. Army or Department of Defense. The authors would like to thank Sam Bell, Ben Farrer, Mike Findley, Adrian Florea, Benjamin Jones, Stan Lee, Nachelle Lopez, Steve Miller, David Montgomery, Sinan Nadarevic, Lisa Troyer, Julie VanDusky-Allen, Spencer Willardson, and Rob Williams for their valuable help in preparing this manuscript. All remaining errors are our own.
}

${ }^{\dagger}$ Email: michaelaallen@boisestate.edu. Contact: Department of Political Science, Boise State University, 1910 University Drive, Boise, ID 83725.

†mail: meflynn@ksu.edu. Contact: Department of Political Science, 019C Calvin Hall, Kansas State University, Manhattan, KS 66506.

§Email: carlamm@ksu.edu. Contact: Department of Political Science, 101C Calvin Hall, Kansas State University, Manhattan, KS 66506.

๑Email: stravers@rand.org. Contact: 4570 Fifth Ave \#600, Pittsburgh, PA 15213. 


\begin{abstract}
How do citizens within countries hosting U.S. military personnel view that presence? Using new cross-national survey data from 14 countries, we examine how different forms of exposure to a U.S. military presence in a country affect attitudes towards the U.S. military, government, and people. We find that contact with U.S. military personnel or the receipt of economic benefits from the U.S. presence correlates with stronger support for the U.S. presence, people, and government. This study has profound implications for the role that U.S. installations play in affecting the social fabric of host nations, and policy implications for the conduct of U.S. military activities outside the United States.
\end{abstract}


From the former Canal Zone in Panama to Ramstein Air Base in Germany, a U.S. military presence has long been a reality for people throughout the world. The United States has maintained overseas deployments of hundreds of thousands of military personnel during the post-War period. Unprecedented in their breadth and activism, these deployments became central to the U.S. policy of deterrence and to the maintenance of the liberal international order. Despite their importance, there is much to learn about the consequences of U.S. military deployments, particularly regarding their effects on host country's populations.

This study examines how social and economic interactions with U.S. military personnel affect individuals' views of the U.S. military presence, the U.S. population, and the U.S. government. We evaluate the effects of the U.S. military presence on individuals' attitudes through two main channels: 1) social capital and 2) economic interests. First, we argue that individual attitudes towards the U.S. military may improve through interactions with U.S. military personnel, thereby increasing U.S. soft power. Second, we argue that the flow of economic resources into the host-state that accompany U.S. military deployments has a positive effect on attitudes. In both cases, we explore the effect of direct contact and the direct receipt of economic benefits, as well as the indirect effects of these factors as transmitted through social networks.

This study builds on previous research by exploring the microfoundations of hierarchical relations between states (Lake 2013). It focuses on the determinants of public attitudes towards the United States which can influence policy outcomes. Research suggests that one of the primary challenges to maintaining long-term overseas deployments is widespread public opposition among host-country citizens to the presence of the U.S. military (Calder 2007; Cooley 2008; Holmes 2014; Vine 2015). These studies moved the field forward in important ways, but we still require a better understanding of the determinants of individual-level opinion formation on these topics. Using original data from a survey of 14 host countries, we explore how exposure to, and interactions with, U.S. military personnel affects individuals' 
attitudes toward the U.S. military's presence in a country. This study sheds new light on the correlates of cross-national attitudes towards the U.S. military. Focusing on noncombat settings, we show that U.S. personnel act as agents of public diplomacy, improving public attitudes and building U.S. soft power through the development of social capital and economic activity. Our argument stands in contrast to others regarding the relationship between the size of a U.S. military deployment and its effects on attitudes within the host country. Given the importance of public opinion to the maintenance of the United States' overseas military presence, this study has pivotal implications for one of the central pillars of post-War U.S. foreign policy.

\section{Research on Military Deployments}

The projection of military power is a fundamental tool of world politics. Contemporary scholarship on international relations focuses on understanding conflict in domestic and international settings (e.g. Putnam 1988; Bueno de Mesquita et al. 2005; Hudson 2005). Integral to these processes is the mobilization and deployment of military personnel abroad (Reveron 2010). The most prominent example - the United States - has, for over 70 years, kept approximately 15\%-30\% of its military personnel throughout Western Europe and East Asia, with smaller deployments in dozens of other countries. Figure 1 shows the location of U.S. military facilities around the globe (Panel A) and the size of the deployments in the 14 countries this study examines (Panel B).

Scholars have long debated the effect of such deployments in terms of state-to-state relations (Harkavy 1989; Ikenberry 2004; Lake 2009a; Wohlforth 1999; Davis 2011) and specific political, economic, and social outcomes (Biglaiser and DeRouen Jr 2009; Jones and Kane 2012; Heo and Ye 2017; Bell, Clay and Martinez Machain 2017; Martinez Machain and Morgan 2013; Allen, Flynn and VanDusky-Allen 2017; Nieman 2016; Braithwaite and Kucik 2017). Related to the concept of hierarchy, some argue that the maintenance of a large 
A

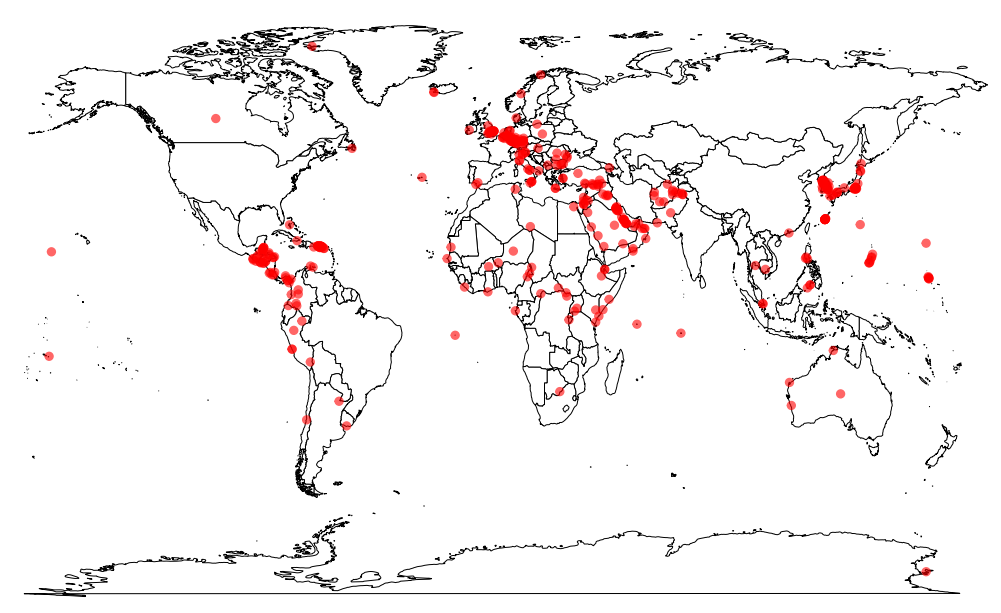

B

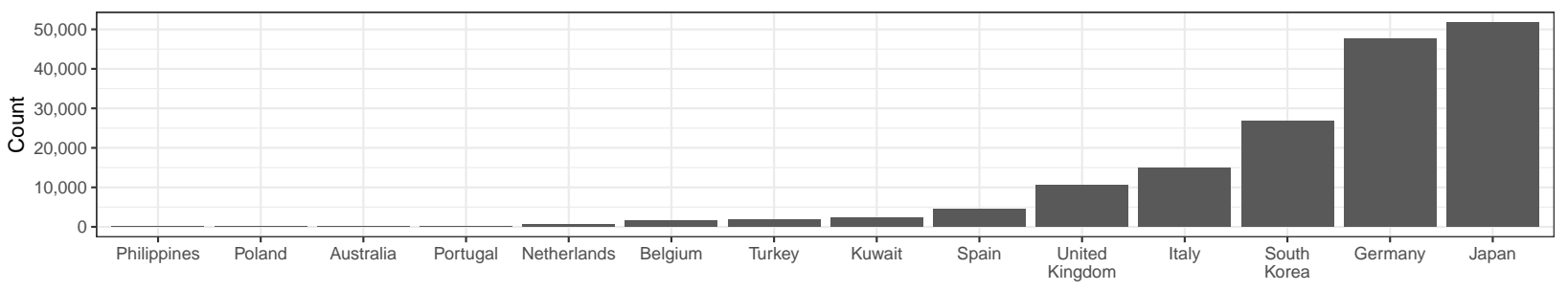

Figure 1: Panel A shows the locations of U.S. military facilities around the globe. Data originally collected by Vine (2015) and supplemented with independent research. Panel B shows the number of active duty, guard, reserve, and DOD civilian U.S. military personnel deployed to select countries covered in this study as of December 30, 2017. Data obtained from the Defense Manpower Data Center (2019).

overseas presence has been crucial to sustaining the liberal international economic order (Lake 2009b; Ikenberry 2011). While informative, existing work has important limits. First, theory often focuses on deployments as representative of more abstract theoretical concepts and tends to focus less on the effects of the deployments themselves on the host environment. Second, while statistical analyses have advanced our understanding on a number of outcomes, they tend to utilize more general cross-national time-series frameworks. This approach can pose a difficulty in establishing linkages between the U.S. military and outcomes of interest, like economic growth, anti-U.S. protests, crime, or public opinion, as ecological inference problems often emerge from using highly aggregated data. 
Existing studies are also unable to explore questions concerning the formation of individual attitudes towards the U.S. presence within a country. These questions carry great importance - if U.S. military activities diminish public support in the host state, then the United States' ability to maintain a military presence becomes more difficult. For example, domestic activists have long contested the U.S. military presence throughout Asia (ChanlettAvery and Rinehart 2012). Alternatively, U.S. military deployments can create economic interests in support of the U.S. presence (Holmes 2014). In short, military deployments have characteristics that plausibly lead to both positive and negative attitudes among host-state residents.

The lack of systematic work on the relationship between U.S. military deployments and mass attitudes also poses challenges for the development of macro-level theories of international order. Lake (2013) argues that the United States has established a series of "contractual" relationships with other states, the sustainability of which relies on public opinion toward the U.S. military presence. In such cases, subordinate states cede authority over foreign policymaking to the U.S. in exchange for the provision of security. Although these theoretical arguments advance our understanding of the international order, they leave the microfoundations of that order unexplored.

The idea of governments ceding foreign policymaking authority to the U.S. in exchange for security guarantees affects domestic political processes. U.S. security guarantees, and any accompanying policy concessions, typically require some level of domestic consent. The potential for public opinion to influence U.S. security cooperation is particularly important given that democracies rank among the largest hosts of overseas U.S. military personnel. Even in non-democracies, public opinion may limit the degree to which host governments can cooperate with the United States. Where public opposition to a foreign military presence increases, the cost to host-state political elites for maintaining these relationships also increases. 


\section{Theoretical Expectations}

Our theoretical focus is on how the U.S. military presence in a state shapes attitudes towards U.S. actors. We evaluate the effects of the U.S. military presence through two main channels: 1) Social capital and 2) economic interests - both of which increase U.S. soft power. We argue that individual attitudes towards the U.S. military may improve simply through interactions with U.S. military personnel, which allow locals to overcome negative stereotypes of Americans. Second, we argue that the flow of economic resources into the host-state that accompany U.S. military deployments will also improve public attitudes. In both cases we explore the effect of direct contacts and the direct receipt of economic benefits, as well as the effects of these factors as transmitted through social networks.

Interactions with U.S. military personnel are distinct from other interactions with U.S. citizens for a few fundamental reasons. U.S. military personnel represent a state security apparatus, which alters the basic character of their interactions as compared to private individuals. Military personnel may be armed, are constrained by two sets of bureaucratic institutions (the U.S. and the dictates of the Status of Forces Agreement), and are enmeshed in a broader unit, base, and culture. While these factors may be similar to a diplomatic attachè, military deployments are more numerous, larger in the footprint they require, and represent the state's capacity for force instead of negotiation. These combined factors make military-civilian interactions unique relative to other U.S.-host-state civilian interactions.

Recent research examines how the military, a traditional hard power tool, can act as a tool of soft power (Atkinson 2014). Nye (2004, 5-6) defines soft power as obtaining a desired outcome through shaping the preferences of others rather than using coercion or economic payments to obtain concessions. For example, cultural and economic influence can reshape actors' preferences to become aligned with those of a major power. Though the U.S. primarily deploys military personnel for security, the military also often engages in what Cull (2008, xv) referred to as public diplomacy, "an international actor's attempt to conduct its 
foreign policy by engaging with foreign publics." Public diplomacy is thus a soft power tool that state actors can use to influence the preferences of the public in other states (Melissen 2005; Goldsmith and Horiuchi 2009).

The preferences of host-state publics matter because they constitute the microfoundations of state preferences. Scholars frame much of the soft power literature around the idea that states become "socialized" to have preferences more aligned with those of the state engaging in soft power projection (Finnemore 1996; Atkinson 2014). The preferences of states and policymakers are not determined purely by external actors - many of them originate from the preferences of individuals (Putnam 1988). In the context of post-War U.S. foreign policy, the spread of U.S. culture to individuals within foreign populations played a pivotal role in creating support for the growth and maintenance of liberal political and economic institutions backed by the U.S. Traditionally regarded exclusively as an instrument of hard power, the U.S. military has played an important role in these socialization processes, shaping mass attitudes and opinions within host countries through a variety of mechanisms.

Our first argument is that, in a non-combat setting, a U.S. military presence can serve as a tool of public diplomacy, creating more positive perceptions of U.S. actors. Contacts with U.S. personnel can create "social capital" that can invest the local population in the welfare of their U.S. military neighbors. As Putnam (2001, 42) states, "merely nodding at someone in the hall generates visible, measurable forms of reciprocity." In host states, American personnel and their dependents can be deeply enmeshed in the local community by marrying into local families, children attending local schools, and establishing local friendships. These types of interactions create both "bridging" and "bonding" opportunities between U.S. personnel and host-state citizens (Woolcock and Narayan 2000). Especially in states where an American presence has existed for decades, these repeated personal interactions serve as a tool of public diplomacy by creating a sense of shared identity or experience. These interactions can be a counterweight to the heavily politicized ethno-nationalist identities that 
Posen $(2014,53)$ describes, and may mitigate their effects among populations that use them to create the impression that U.S. forces unduly influence the host state.

Individuals interacting with U.S. personnel gain exposure to members of the military as individuals rather than as an abstract concept. One journalist in Lima, Peru noted that, for many locals, there existed a stereotype of members of the American military as "muscular men with tattoos waving around the flag and yelling about liberty and democracy" (Interview with Peruvian journalist 2018). These stereotypes are often influenced by media portrayals, but are likely to weaken through direct personal or indirect network contacts. Interviews that we conducted with civilian and military personnel reinforce this point. A U.S. Government Relations Officers at a U.S. Army base in Germany noted that she offers tours of the base for local council members to dispel myths about Americans. She noted that "[the Germans] all think we are spies and trashy people; they think we don't sort our trash," so she includes the base's recycling facilities in her tours to dispel that myth (Government Relations Officer Interview 2019). A German anti-base activist admitted difficulties with mobilizing support for the cause because local communities have a deep, long-lasting relationship with the U.S. military. He noted that they have common parties, public events, and "friendship meetings," which enhance the local military-community relationship (Interview with German Peace Activist 2019).

While we argue that interactions will lead to more positive attitudes, there is a long history of social and economic ills associated with the presence of U.S. military forces, and interactions with members of the U.S. military can in fact be negative. Perceptions of the U.S. presence in Japan, South Korea, and Germany have often become entangled with cases of sexual assault, drug use, and other crimes (Nelson 1987; Moon 1997). More recently, the Philippines experienced several high profile crimes by U.S. service members against locals, including a murder in 2002, a rape in 2005, and the crash of a drone in a civilian community (Simbulan 2009). However, it is not clear that such interactions are the norm - the benign 
day-to-day interactions between U.S. personnel and host-state population are likely far more numerous than these sorts of negative experiences. As Allen and Flynn (2013) show, while particularly egregious crimes involving U.S. personnel garner significant public attention, they do not appear to represent typical patterns of interactions between military personnel and host-state civilians. We argue that these more frequent interactions should constitute a much stronger determinant of individual attitudes than more isolated incidents.

This logic leads to our first hypothesis:

Hypothesis 1a. Individuals who have had direct contact with a member of the U.S. military will be more likely to express positive views of the American presence/government/people.

We also expect an individual's interactions with U.S. military personnel will affect the attitudes of other people in that individual's social network by decreasing the network's prejudice (Liebkind and McAlister 1999). There is a long line of research that shows an individual's social network can influence their political opinions (Levine 2005). This happens through the construction of political identities within the family (Jennings, Stoker and Bowers 2009) and also within the context of an individual's chosen social network of friends (Zuckerman 2005). Individuals within a social network take cues from others within the group about the value and importance of issues, and the likelihood of threats from outside groups.

Individuals use networks as shortcuts to gather information (Huckfeldt 2001). Given that a clear majority of individuals in our survey have not had direct contact with U.S. military personnel, we argue that they will look to social networks to gain information about the U.S. military that will then shape their attitudes towards the U.S. military presence within a host country. Those individuals who do interact with U.S. personnel possess more information regarding the U.S. military presence, and thus serve as an important bridge between the U.S. military community and the broader host-state communities in which they 
are embedded. Existing work also finds that contact with more knowledgeable members of the social network helps to avoid ambivalent attitudes (McClurg 2006).

As with direct personal contact, having members of one's network interact with the U.S. military should also lead to more positive views of Americans (Wright et al. 1997). Research on the contact hypothesis finds that having (ingroup) friends who interact with outgroups leads to decreased amounts of prejudice, and therefore more positive views of outgroups, by creating an environment of tolerance (Pettigrew et al. 2007; Liebkind and McAlister 1999). Network interactions have the added benefit of decreasing prejudice without the associated anxiety that interacting with a member of an outgroup would produce, while also being generalizable to the outgroup as a whole (as opposed to a single individual) (Wright et al. 1997; Paolini et al. 2004). Indirect contact also has the added benefit of being less affected by self-selection - it is easier for individuals to select themselves into or out of contact with the Americans than it is to control their network's interactions with the U.S. military. We refer to this dynamic as a network contact and derive our second contact-based hypothesis: Hypothesis 1b. Individuals who have had network contact with a member of the U.S. military will be more likely to express positive views of the American presence/government/people.

Our second causal channel is that a U.S. presence will affect individuals' attitudes through the distribution of economic benefits to the population. U.S. military deployments often involve the transfer of substantial economic resources. Figure 2 shows the annual cost of maintaining the U.S. military presence in the countries we examine, with total costs for fiscal year 2020 ranging from $\$ 23$ million (Poland) to $\$ 8.1$ billion (Germany). Of these transfers, substantial amounts often flow to local contractors who provide services to help maintain the U.S. presence. Salaries paid to U.S. personnel also often flow into the local economy as U.S. personnel and their families spend money in local businesses.

Research shows that economic interests play an important role in shaping foreign policy attitudes at both the mass and elite level. Kleinberg and Fordham (2011) demonstrate that 


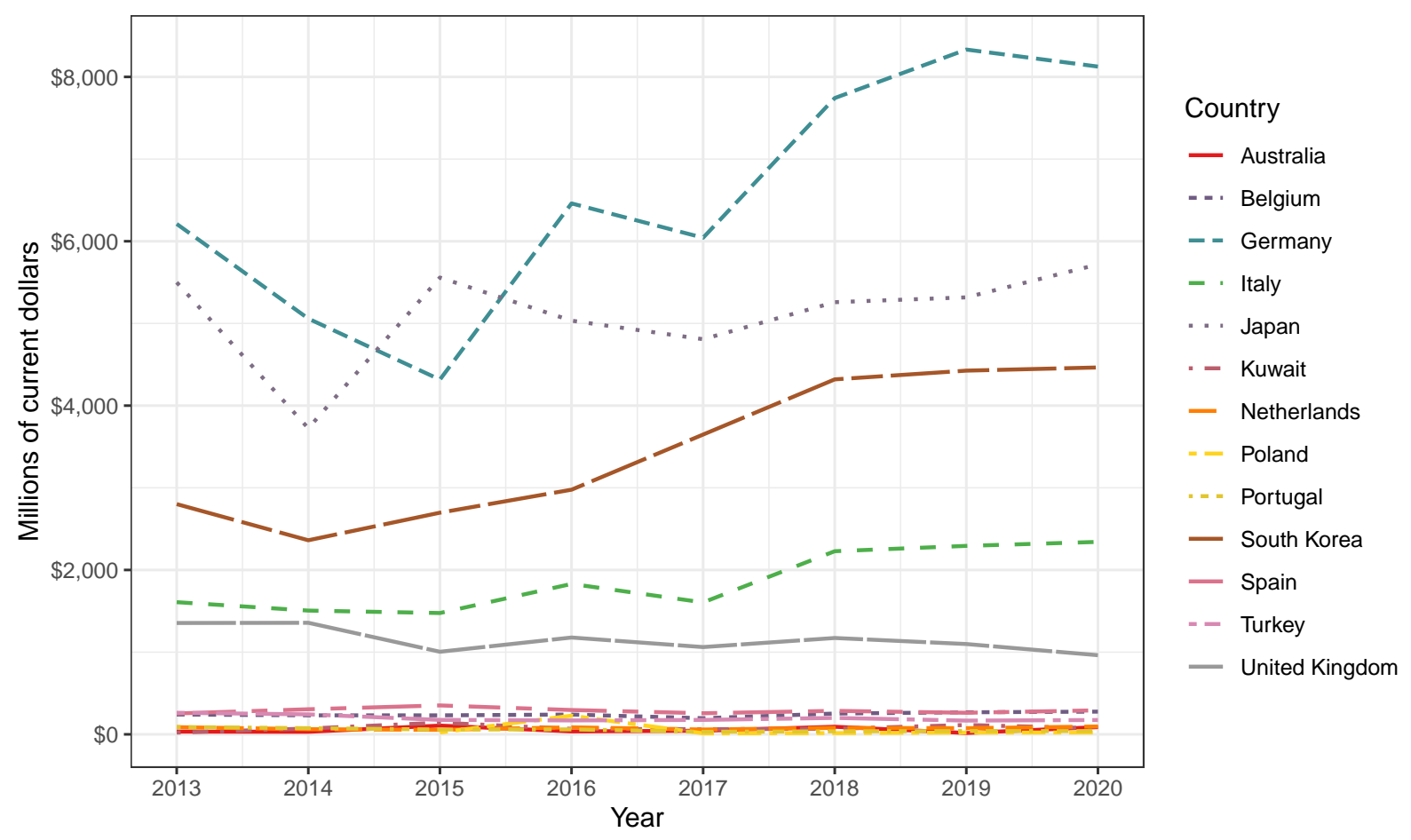

Figure 2: Annual costs of maintaining U.S. military presence in select countries, 20132020. Millions of current U.S. dollars. Fiscal years 2019 and 2020 use budget estimates. Department of Defense records exclude information on the Philippines. Data obtained from Office of the Under Secretary of Defense (Comptroller) / Chief Financial Officer (Various Years).

international trade affects individuals' attitudes on foreign policy issues, and whether they perceive other countries to be friendly or threatening. Individuals who benefit from economic exchange with a country tend to express positive attitudes towards that country and, when individuals stand to lose from trade with a country, they tend to view it as more threatening. The capital flows resulting from the U.S. presence in many countries (e.g. Germany or Japan) are often substantial, and host-country firms receive tens-of-millions of dollars from the U.S. military every year for their services.

We expect such capital flows to exert a positive effect on mass attitudes towards the U.S. in a way that is similar to foreign aid. Research on foreign aid suggests that recipients of aid view donor states more favorably, and at times as more effective, than their own governments 
(Milner and Tingley 2013). ${ }^{1}$ As Goldsmith, Horiuchi and Wood $(2014,88)$ argue, "targeted, sustained, effective, and visible" aid is most effective at influencing perceptions of the donor. Likewise, a U.S. presence can be effective as a form of aid. When it comes to foreign aid, misattribution can be a problem that impedes the use of aid to shape positive perceptions of the donor - those individuals who benefit from the aid may not know who is providing that benefit (Goldsmith, Horiuchi and Wood 2014). For example, someone who received medical care from a foreign physician may not know the nationality of that physician. A U.S. military presence that provides economic benefits to the host state can be an effective way of solving the attribution problem because people can easily identify U.S. military personnel with the United States (Flynn, Martinez Machain and Stoyan 2019).

We argue that the U.S. military presence in a country will have a positive effect on perceptions of the U.S. in individuals who see tangible economic benefits from that presence. In the case of non-combat deployments, the beneficiaries of either a service that the U.S. military provides (vaccinating children during outreach engagements) or an economic benefit (members of the military patronizing local businesses) will be most likely to hold positive views of the U.S. and its military.

The economic effects of a U.S. military presence are typically felt across income levels. Elite actors are more likely to hold business interests that benefit from contracts with the U.S. military, or that benefit from the consumption of U.S. personnel (Interview with Panamanian Journalist and Former Government Official 2018). Lower income individuals may be employed by businesses that provide services to U.S. facilities, and are more likely to benefit from humanitarian services provided by the U.S. military. One embassy official noted that when the USNS Comfort carried out a mission in Colombia in 2007, locals treated it as a

\footnotetext{
${ }^{1}$ There are some caveats: Some work finds that aid has no effect on perceptions of donor states (Böhnke and Zürcher 2013) or that U.S. aid can actually exacerbate anti-Americanism in cases in which the aid creates "winners and losers" within a society (Tokdemir 2017).
} 
festive occasion and came out to welcome the U.S. personnel who were bringing aid. The interview subject noted that the locals knew that these were members of the U.S. military and attributed the aid to the U.S. military (Interview with Embassy Staff \#4 2018). Given the cross-cutting nature of economic and humanitarian activity from a U.S. presence, we expect it to have a general effect on attitudes. We thus derive our next hypothesis:

Hypothesis 2a. Individuals who have received direct economic benefits from the U.S. military will be more likely to express positive views of the American presence/government/people.

Like interpersonal contact, we also expect that if someone in an individual's social network has benefited economically from the U.S. military, the individual is more likely to think positively of the U.S. As with individuals' more general experiences, we expect individuals to exhibit more favorable attitudes towards the U.S. military when they have knowledge of friends or family members who receive economic benefits from the U.S. military presence. We refer to this phenomenon as network benefits. We thus derive our final hypothesis:

Hypothesis $\mathbf{2 b}$. Individuals whose social networks have benefited economically from the U.S. military will be more likely to express positive views of the American presence/government/people.

\section{Research Methodology}

We conducted a survey in 14 countries, with $\approx 1,000$ respondents in each country. ${ }^{2}$ We administered the surveys online, using two firms, to approximately nationally representative populations based on gender, age (over the age of 18), and income. The survey contained 50 questions with estimated completion times at 10-15 minutes. We made the surveys available

\footnotetext{
${ }^{2}$ Our sample does not contain states with active combat operations. All respondents experience interactions with the United States military under a non-combat setting. The U.S. presence came from an invasion with formal combat operations ending in 1945 in Germany, Italy, and Japan, but we expect that the continuation of the U.S. presence is consensual given the repeated signing of Status of Forces Agreements. We discuss our sample selection processes in the supplementary appendix.
} 
in each national language in the country surveyed (Arabic, Dutch, English, Filipino, French, German, Italian, Japanese, Portuguese, and Turkish). Respondents completed the surveys across a two-month time period from early September until early November of $2018 .^{3}$

\section{Dependent Variables}

To examine the relationships between contact, economic benefits, and individual attitudes we focus on three outcome variables of interest. For our primary dependent variable, we ask about respondent attitudes towards the presence of U.S. military personnel. We asked respondents the following question "In general, what is your opinion of the presence of American military forces in [respondent's country]?" The answers correspond to a sixpoint scale: 1) "Very favorable", 2) "Somewhat unfavorable", 3) "Neutral", 4) "Somewhat favorable", 5)"Very favorable", and 6) "Don't know/Decline to answer".

Our theoretical argument focuses in part on U.S. military personnel as agents of public diplomacy. While our primary focus is on how different types of contact with U.S. personnel affects attitudes towards the U.S. military presence, we expect that these same forms of contact may also influence views of other actors. A country's people are not synonymous with their government, and while a government's policies and actions might be unpopular with international audiences, that unpopularity may not transfer to its people (McGillivray and Smith 2018). We explore this proposition by analyzing whether factors that predict views of the U.S. presence extend to the American government and people.

Accordingly, we include two additional dependent variables. We first asked respondents, "In general, what is your opinion of the American government?" Then, to get at attitudes

\footnotetext{
${ }^{3}$ We supplemented our large-N quantitative analysis with qualitative interviews with a variety of U.S. and host-country government officials, military personnel, activists, and journalists conducted in Panama, Peru (summer 2018), England, and Germany (summer 2019). Given various constraints, Panama and Peru are not covered by our survey data, but we include components of those interviews to supplement the quantitative evidence we provide. We discuss this more in the supplementary appendix.
} 
towards the American people we asked, "In general, what is your opinion of the American people?" We measure these variables using the same six response categories we use to measure attitudes towards the U.S. military presence. For estimation purposes, we collapse the dependent variable responses down to four categories: 1) Positive, 2) Negative, 3) Neutral, and 4) Don't know/Decline to answer.

\section{Main Independent Variables: Interactions}

Our four primary variables of interest relate to respondents' interactions with the U.S. military. First, we ask respondents "Have you personally had direct contact with a member of the American military in [respondent's country]?" Second, we ask if a close friend, or a family member, "had direct contact with a member of the American military stationed in [respondent's country]?" Our expectation is that both direct and network contacts will correlate with more favorable views of the U.S. military presence.

To measure economic benefits we asked respondents two questions. For direct benefits we asked "Have you personally received a direct economic benefit from the American military presence in [respondent's country]? Examples include employment by the U.S. military, employment by a contractor that does business with the U.S. military, or ownership/employment in a business that frequently serves U.S. military personnel." We asked the same question about whether a family member or a close friend received these benefits. ${ }^{4}$

\section{Demographics and Attitudes}

We included a series of questions to capture the particular demographic attributes of the respondents that can influence perceptions of the U.S. and its military.

\footnotetext{
${ }^{4}$ In order to avoid priming respondents with a positive association before asking them about their perceptions, we first asked all of the questions about the respondent's views on the U.S. government/people/influence/military before asking them about any economic benefits they may have received from the U.S. military.
} 
We include the respondent's age as measured by a six-point ordinal scale, starting with an 18-24 bracket, increasing in ten year increments up to $\geq 65$. Age can be a strong determinant of attitudes. Across qualitative interviews, one recurring comment was that students were the most likely to mobilize against the presence of U.S. forces (Interview with Panamanian Journalist 2018). Given that students tend to belong to younger age cohorts, we expect that age will positively correlate with positive perceptions of the United States. ${ }^{5}$

We also adjust for the respondent's self-identified gender. We asked respondents "What is your gender?", providing four response options, including "Male", "Female", "Non-binary", and "None of the above". ${ }^{6}$ Given previous findings on women's attitudes towards militarism, and the greater negative effects that conflict can have on women, we expect women are less likely to be supportive of a U.S. military presence (Hudson and Leidl 2015).

We asked for the respondent's left-right ideological orientation by priming them on what the left-right spectrum is, and then asking them to place themselves on a left-right political spectrum that ranged from 1 (far-left) to 10 (far-right). Across qualitative interview subjects, many mentioned that those most likely to mobilize against a U.S. presence, or to generally have negative perceptions of the U.S. military, were individuals who identified as leftist (Interview with former President 2018; Public Affairs Officer Interview 2018; Interview with Embassy Staff 2018).

Respondents self-reported their annual income by placing themselves in income percentile brackets for their country. ${ }^{7}$ Given competing narratives about the relationship between

${ }^{5}$ In the online appendix we explain how in states that experienced a U.S. invasion and reconstruction (Germany and Japan), older groups may have more complex views on the U.S. presence

${ }^{6}$ Six of the countries did not receive the "none of the above" option due to the firm requiring an answer to fulfill inclusion criteria.

${ }^{7}$ Because we used two different survey firms, one firm used quintiles while the other used sextiles. While not ideal, this still provides a linear measure of income. We adjusted income quintiles or sextiles for each country. 
income and support for the United States and the cross-cutting nature of different types of U.S. economic activity in host states, we remain agnostic about our expectations here.

We also adjust for respondents' educational attainment. We gave respondents an open prompt to fill in the number of years of formal education they had completed. Previous surveys indicate that further education tends to lead individuals to become more leftist in their political orientation (Pew Research Center 2016; Gouldner 1979). Whether education has its own independent effect on views of the U.S. is thus unclear, and the results will shed some light on this connection between education and political leanings. ${ }^{8}$

We include the respondent's religion. We asked "What is your religion, if any?" The options available were Christianity (Protestant), Catholicism, Islam, Agnostic/Atheist, Hinduism, Buddhism, Shinto, Judaism, Mormonism, Local Religion, Decline to Answer, and "Other," which allowed a free form box to explain. We expect some religious affiliations to affect individuals' attitudes, particularly where they tap into aspects of social conservatism or political cleavages that elicit anti-American sentiment. For example, we expect that Muslims will have more negative perceptions of the United States, given recent history of U.S. foreign policy and the multiple ongoing wars in predominantly Muslim countries (Nisbet et al. 2004).

We also include a series of attitudinal responses. Attitudes regarding the U.S. military presence in a country, as well as the U.S. government and people, may reflect more general views held by individual respondents. First, we include a question asking respondents "In general, how important is it to you that you live under a democratic government?" Given the long history of democracy promotion in U.S. foreign policy, we expect responses to this question to positively correlate with perceptions of the United States. Second, we include two questions that capture respondent attitudes toward U.S. influence in their country. We

\footnotetext{
${ }^{8}$ We omit a small number of responses indicating over 25 years of formal education. Given the broader distribution of responses, we treat these as erroneous.
} 
asked respondents to judge the amount of influence the United States has on their country. We also asked respondents to evaluate whether that influence was good or bad. While this question relates to those that comprise the dependent variables, it is different enough to warrant inclusion in the model. It is possible for individuals to have a negative evaluation of the American influence in their specific country but to generally view the U.S. military (as well as the U.S. government and population) in a positive way. ${ }^{9}$

Next, we asked about respondents' minority status: "Do you identify as a racial, ethnic, or religious minority?" We expect that because of the historical U.S. promotion of human rights, minority groups (which may be at greater risk for repression) will be more supportive of a U.S. military presence in their country, which respondents may see as protecting them against repression by the host government (Bell, Clay and Martinez Machain 2017). Further, U.S. military bases are often located in communities with high minority populations, and members of these populations often work on or near military bases and receive economic benefits from the presence. This dynamic may lead minority populations to have more positive perceptions of the U.S., because of positive contractual relationships.

Finally, we include a series of variables measured at the country and sub-national levels that may affect individuals' attitudes. First, we expect some individuals to have greater opportunities to interact with and/or benefit from a U.S. military presence. To help adjust for variation in opportunities to interact with U.S. personnel we also include a binary variable indicating whether or not there is a U.S. military facility located within a given province/region $(1=Y e s ; 0=N o) .{ }^{10}$ We also include the log of the number of U.S. military

\footnotetext{
${ }^{9}$ Notably, several of our variables may conceptually proxy political ideology. While these variables measure some concepts that may be orthogonal to a normal left-right dimension (e.g. security) or capture nuanced views, our supplemental appendix contains models that remove all variables that conceptually relate to ideology. Our results remain consistent.

${ }^{10}$ We coded this variable using data originally collected by Vine (2015) and we supplemented with inde-
} 
and civilian personnel deployed to the country as of December 2017. This variable corresponds to overall opportunities for interaction, as well as aggregate financial flows (Defense Manpower Data Center 2019).

Using publicly available data on U.S. military construction spending at overseas locations, we constructed a spatially-weighted province/region-level indicator of US military spending within each country. We spatially weight this variable using the sum of all U.S. military construction spending within a country, combining the total amount of spending within a given province/region with the inverse distance weighted sum of spending in all other provinces/regions. This provides us with a more objective measure of the economic benefits that accompany a U.S. military presence, while also allowing us to address the possibility that there may be spillover effects from such spending on attitudes in neighboring provinces/regions (United States Department of Defense Various Years).

We expect states facing more challenging security environments to be more favorably disposed to the U.S. presence. We include a measure of each state's "threat environment" as a means of assessing differences in baseline opinions across countries. Using the measure developed by (Leeds and Savun 2007) as a rough guide, we used United Nations ideal point data for all dyads in 2017. We begin with UN ideal point distance data for each state in our sample and all possible dyad pairings with those states (Voeten, Strezhnev and Bailey 2009, v21.0). We calculate the median absolute distance in ideal points for all dyads. We then drop all dyads where 1) the absolute ideal point distance is $\leq$ the median value, and 2) the two states belong to a mutual defense pact. Finally, we sum the 2017 military expenditures values for all remaining states to provide a picture of the total military expenditures for non-allied states that are not closely aligned with the referent state, according to the UN voting data (Stockholm International Peace Research Institite (SIPRI) 2019). We use the $\log$ of this variable in our models.

pendent research. 
We also expect political institutions to affect attitudes towards the U.S. We adjust for two such institutions herein. First, we include a binary variable indicating whether the country in which the respondent resides is in an active defense pact with the United States $(1=Y e s ; 0=N o)$ (Leeds et al. 2002, v4.01). Second, we adjust for the respondent's country's level of democracy using the Polity 21-point regime type indicator (Marshall, Jaggers and Gurr 2011, v2017).

We also adjust for economic conditions and relationships between the U.S. and the respondent's country. We include a measure of each country's GDP in 2017 dollars. This variable was obtained from the World Bank's World Development Indicators (2018). We also adjust for the level of total bilateral trade between the U.S. and the respondent's country in 2017. These data were obtained from the International Monetary Fund's (IMF) Direction of Trade Statistics (2018). We use the log of both GDP and trade in our models.

Last, to account for between-country variation in the probability of encountering U.S. citizens, we include the log of the total number of U.S. exchange students to the country in 2017 (Institute for International Education 2018).

\section{Estimation Strategy}

We estimate our models using a series of multilevel categorical Bayesian logistic regressions. Multilevel models allow us to treat observations as nested within groups - for this study, individuals nested within countries. It is possible that perceptions of the U.S. military are generally less favorable in Turkey than they are in the U.K. The multilevel model allows us to account for these between-group differences by treating group-level intercepts as a random variable for the model to estimate.

Collapsing the original six-category variable into four general categories and fitting a choice model also offers us a number of analytical and inferential advantages. It is possible that contact with U.S. personnel may increase both positive and negative sentiments. 
Though we hypothesize contact should correlate with more favorable attitudes, historical and media accounts of U.S. military personnel overseas are full of references of crime, environmental degradation, and other social ills. Further, the primary alternative - turning the response variable into ordered outcome variables - would require that we drop "Don't know/Decline to answer" responses from our model. These responses account for approximately $4.5 \%$ of our total sample and are substantively interesting in their own right. Previous research has pointed to the insight that researchers can gain by modeling survey response categories like "Don't know" (Kleinberg and Fordham 2018). Including them in our models allows us to better understand the relationship between our variables of chief theoretical interest and individuals' attitudes. Figures and tables providing further descriptive information on our independent variables can be found in the supplementary online appendix. ${ }^{11}$

\section{Results}

Figure 3 previews how contact with, and the receipt of economic benefits from, U.S. military personnel relate to attitudes towards the U.S. military personnel, government, and people. These questions ask about 1) having personal contact with U.S. military personnel, 2) having a friend or family member who had personal contact with U.S. military personnel, 3) receiving personal economic benefits from the U.S. military presence in a country, or 4) having a friend or family member who has received an economic benefit from U.S. military presence. Response options were: "Yes", "No", or "Don't know/Decline to answer". Each tile represents the modal response in each country for each question-based subgroup (for example, the modal response for individuals in Germany responding "Yes" to whether they have had personal contact with U.S. military personnel). Red indicates "Very unfavorable"

\footnotetext{
${ }^{11}$ We thank a reviewer for suggesting this approach.
} 


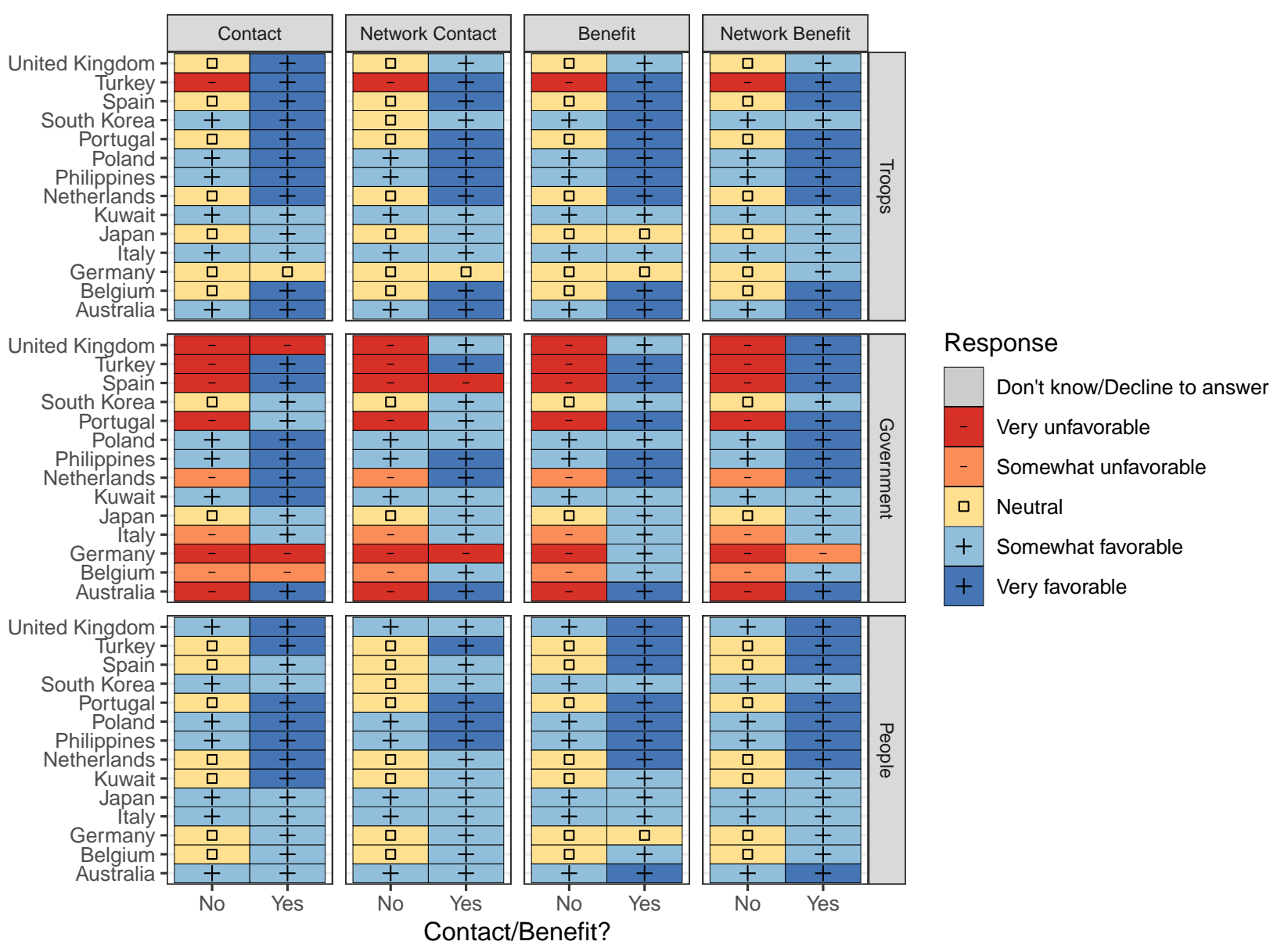

Figure 3: Modal response towards reference group (row) by respondent country and type of contact with U.S. military (column headers).

as the modal response, while dark blue indicates a "Very favorable" modal response. ${ }^{12}$

Some notable patterns emerge. First, among those who responded "No" to any of the questions, we find generally neutral to somewhat favorable attitudes towards U.S. military personnel and the U.S. people. Turkey is the lone exception; we find a modal response of "Very negative" for individuals' attitudes towards the U.S. military presence in their country. Alternatively, we find largely negative attitudes towards the U.S. government across all four

${ }^{12}$ We omit the "Don't know/Decline to answer" response groups from the contact and benefits questions because they overwhelmingly respond "Neutral" when asked. 
questions. Poland, The Philippines, and Kuwait stand out as the only countries where the modal response among individuals responding "No" to the contact and benefits questions is positive. In nearly half of the countries surveyed, those reporting no contact or benefit predominantly expressed "Very unfavorable" attitudes towards the U.S. government. This is noteworthy given that the "No" category is the clear modal category for both contacts and benefits.

Second, those who responded "Yes" to the contact and/or benefits questions yield a modal response of either "Somewhat favorable" or "Very favorable" in nearly all countries for each of the three outcome variables. When looking at the contact questions in the United Kingdom, Germany, and Belgium, the modal response was either "Somewhat unfavorable" or "Very unfavorable" for attitudes towards the U.S. government. Regarding economic benefits, we find "Neutral" as the modal response in Germany and Japan for attitudes towards the U.S. military. For the network benefits question we find the modal response in both Germany and Japan is "Somewhat favorable".

Overall, Figure 3 suggests that direct and network contact with U.S. military personnel, economic benefits, and network benefits, correlate with more positive attitudes towards the three groups of interest. The relatively unfavorable attitudes expressed by residents of some of the United States' closest allies are noteworthy. This figure provides us with a preliminary snapshot of the relationship between contact and benefits and mass attitudes.

The descriptive analysis is a useful starting point, but there are other variables that contribute to shaping individuals' attitudes towards the groups of interest. Tables 1, 2, and 3 show the results of our multilevel categorical logit models. Each table looks at attitudes towards the U.S. military presence, U.S. government, and U.S. people, respectively. ${ }^{13}$ Each column shows the results of one of the three possible responses, with "Neutral" serving as

\footnotetext{
${ }^{13} \mathrm{~A}$ full version of these tables, which include control variables, is available in the online appendix. Similarly, see the appendices for model diagnostic information and robustness checks.
} 
This is an author-produced, peer-reviewed version of this article. The final, definitive version of this document can be found online at American Political Science Review, published by Cambridge University Press. Copyright restrictions may apply. doi: 10.1017/S0003055419000868

Table 1: Multilevel categorical Bayesian logistic regression models predicting positive attitudes towards U.S. troops. Neutral attitudes are the reference category.

\begin{tabular}{|c|c|c|c|}
\hline Personal Contact & Response: Positive & Response: Negative & Response: Don't know/Decline \\
\hline $\begin{array}{l}\text { Personal Contact } \\
\text { PC: Don't know/Decline to answer }\end{array}$ & $-0.401[-0.793:-0.013]^{*}$ & $-0097[-0.535 \cdot 0.332]$ & $0558[-0027 \cdot 1120]$ \\
\hline PC: Yes & $0.578[0.389 ; 0.769]^{*}$ & $0.255[0.022 ; 0.489]^{*}$ & $-0.715[-1.474 ;-0.032]^{*}$ \\
\hline \multicolumn{4}{|l|}{ Network Contact } \\
\hline NC: Don't know/Decline to answer & $0.126[-0.137 ; 0.384]$ & $0.036[-0.278 ; 0.345]$ & $-0.702[-1.257 ;-0.171]^{*}$ \\
\hline NC: Yes & $0.210[0.031 ; 0.395]^{*}$ & $0.158[-0.069 ; 0.383]$ & $-0.663[-1.287 ;-0.082]^{*}$ \\
\hline \multicolumn{4}{|l|}{ Personal Benefit } \\
\hline PB: Don't know/Decline to answer & $-0.260[-0.590 ; 0.077]$ & $-0.323[-0.714 ; 0.066]$ & $0.442[-0.033 ; 0.911]$ \\
\hline PB: Yes & $-0.093[-0.339 ; 0.155]$ & $-0.439[-0.814 ;-0.077]^{*}$ & $-0.432[-1.322 ; 0.359]$ \\
\hline \multicolumn{4}{|l|}{ Network Benefit } \\
\hline $\begin{array}{l}\text { NB: Don't know/Decline to answer } \\
\text { NB: Yes }\end{array}$ & $\begin{array}{c}-0.199[-0.484 ; 0.089] \\
0.538[0.298 ; 0.783]^{*}\end{array}$ & 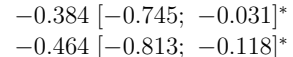 & 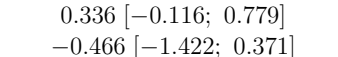 \\
\hline Random Effects & & & \\
\hline $\begin{array}{l}\text { N } \\
\text { Groups } \\
\text { Std. Dev. }\end{array}$ & $\begin{array}{l}12287 \\
14 \\
0.402\end{array}$ & $\begin{array}{l}12287 \\
14 \\
0.555\end{array}$ & $\begin{array}{c}12287 \\
14 \\
0.432\end{array}$ \\
\hline
\end{tabular}

the reference category in each table.

To facilitate interpretation of our primary variables, Figure 4 plots the coefficients from these models. Each column represents one of the three groups of interest. Each facet row represents the coefficients associated with one of the contact/benefit variables. The plotted coefficients correspond to one of the three choice equations from each model predicting attitudes towards one of the three groups (e.g. positive or negative attitudes towards U.S. military personnel). The percentage values next to each coefficient represent the percentage of the coefficient's total distribution that falls above/below 0. We focus primarily on "Yes" responses to the contact and benefits questions, as well as the positive/negative responses to the dependent variable categories.

A "Yes" response to the personal contact variable correlates positively with both positive and negative attitudes towards both the U.S. military and U.S. people. Compared to most of the other coefficients, these are relatively large, roughly equal to an increase of $15 \%$ in the probability of a positive response. These individuals are also generally less likely to give a response of "I don't know/Decline to answer." In all of these cases $>98 \%$ of the coefficient distributions fall above or below 0. Alternatively, we find that direct contact with U.S. military personnel does not correlate strongly with attitudes towards the U.S. government. In the case of both positive and negative responses, both coefficients are close to 0, though 
Table 2: Multilevel categorical Bayesian logistic regression models predicting positive attitudes towards American government. Neutral attitudes are the reference category.

\begin{tabular}{|c|c|c|c|}
\hline & Response: Positive & Response: Negative & "Response: Don't know/Decline \\
\hline $\begin{array}{l}\text { Personal Contact } \\
\text { PC: Don't know/Decline to answer }\end{array}$ & $-0.514[-0.925 ;-0.112]^{*}$ & $-0.699[-1.099 ;-0.296]^{*}$ & $-0.276[-1.043: 0.480]$ \\
\hline PC: Yes & $0.107[-0.105 ; 0.321]$ & $0.065[-0.157 ; 0.287]$ & $0.000[-0.769 ; 0.716]$ \\
\hline \multicolumn{4}{|l|}{ Network Contact } \\
\hline NC: Don't know/Decline to answer & $0.176[-0.120 ; 0.474]$ & $-0.102[-0.396 ; 0.191]$ & $0.288[-0.375 ; 0.937]$ \\
\hline NC: Yes & $0.232[0.027 ; 0.439]^{*}$ & $0.321[0.109 ; 0.539]^{*}$ & $0.053[-0.695 ; 0.754]$ \\
\hline \multicolumn{4}{|l|}{ Personal Benefit } \\
\hline PB: Don't know/Decline to answer & $0.035[-0.312 ; 0.379]$ & $-0.520[-0.876 ;-0.170]^{*}$ & $0.239[-0.398 ; 0.858]$ \\
\hline PB: Yes & $0.319[0.060 ; 0.581]^{*}$ & $-0.208[-0.520 ; 0.102]$ & $0.441[-0.371 ; 1.209]$ \\
\hline \multicolumn{4}{|l|}{ Network Benefit } \\
\hline $\begin{array}{l}\text { NB: Don't know/Decline to answer } \\
\text { NB: Yes }\end{array}$ & $\begin{array}{c}-0.058[-0.375 ; 0.256] \\
0.077[-0.172 ; 0.325]\end{array}$ & $\begin{array}{c}-0.121[-0.431 ; 0.188] \\
-0.304[-0.594 ;-0.013]^{*}\end{array}$ & $\begin{array}{c}0.066[-0.535 ; 0.641] \\
-0.569[-1.570 ; 0.350]\end{array}$ \\
\hline Random Effects & & & \\
\hline $\begin{array}{l}\text { N } \\
\text { Groups } \\
\text { Std. Dev. }\end{array}$ & $\begin{array}{c}12287 \\
14 \\
0.47\end{array}$ & $\begin{array}{c}12287 \\
14 \\
1.054 \\
\end{array}$ & $\begin{array}{c}12287 \\
14 \\
0.253\end{array}$ \\
\hline
\end{tabular}

Table 3: Multilevel categorical Bayesian logistic regression models predicting positive attitudes towards American people. Neutral attitudes are the reference category.

\begin{tabular}{|c|c|c|c|}
\hline & Response: Positive & Response: Negative & Response: Don't know/Decline \\
\hline $\begin{array}{l}\text { Personal Contact } \\
\text { PC: Don't know/Decline to answer }\end{array}$ & $-0.484[-0.833 ;-0.136]^{*}$ & $-0.310[-0.758 ; 0.132]$ & $0.282[-0.481: 1.030]$ \\
\hline PC: Yes & $0.208[0.034 ; 0.384]^{*}$ & $0.037[-0.214 ; 0.283]$ & $-0.271[-1.171 ; 0.529]$ \\
\hline Network Contact & & & \\
\hline NC: Don't know/Decline to answer & $-0.037[-0.282 ; 0.208]$ & $0.073[-0.255 ; 0.397]$ & $0.427[-0.242 ; 1.073]$ \\
\hline NC: Yes & $0.235[0.062 ; 0.406]^{*}$ & $0.294[0.058 ; 0.530]^{*}$ & $-0.049[-0.883 ; 0.721]$ \\
\hline Personal Benefit & & & \\
\hline PB: Don't know/Decline to answer & $-0.119[-0.419 ; 0.187]$ & $-0.411[-0.840 ; 0.002]$ & $0.103[-0.572 ; 0.756]$ \\
\hline PB: Yes & $0.041[-0.195 ; 0.278]$ & $-0.127[-0.502 ; 0.239]$ & $0.809[-0.044 ; 1.587]$ \\
\hline Network Benefit & & & \\
\hline NB: Don't know/Decline to answer & $0.223[-0.046 ; 0.497]$ & $0.263[-0.104 ; 0.631]$ & $0.225[-0.405 ; 0.826]$ \\
\hline $\begin{array}{l}\text { NB: Yes } \\
\text { Random Effects }\end{array}$ & $0.099[-0.124 ; 0.323]$ & $0.036[-0.296 ; 0.366]$ & $-0.864[-2.093 ; 0.214]$ \\
\hline $\begin{array}{l}\text { Groups } \\
\text { Std. Dev. }\end{array}$ & $\begin{array}{l}12287 \\
14 \\
0.552 \\
\end{array}$ & $\begin{array}{l}12287 \\
14 \\
0.376 \\
\end{array}$ & $\begin{array}{c}12287 \\
14 \\
0.528\end{array}$ \\
\hline
\end{tabular}

$70-84 \%$ of their distributions fall above 0 . These results suggest that direct interpersonal contact does not uniformly correlate with more positive views of all U.S. actors, but appears to create more informed judgments towards certain groups. Personal contact yields a larger coefficient in predicting positive attitudes as compared to negative attitudes, suggesting that while contact may increase both, it is more strongly correlated with positive attitudes. Notably, the correlation holds even after adjusting for subjective and objective indicators of economic benefits.

We also find that network contact correlates clearly with a higher probability of expressing a positive attitude across all three groups, though the coefficients are generally smaller in magnitude as compared to direct contact. Similarly, we find evidence of a positive 


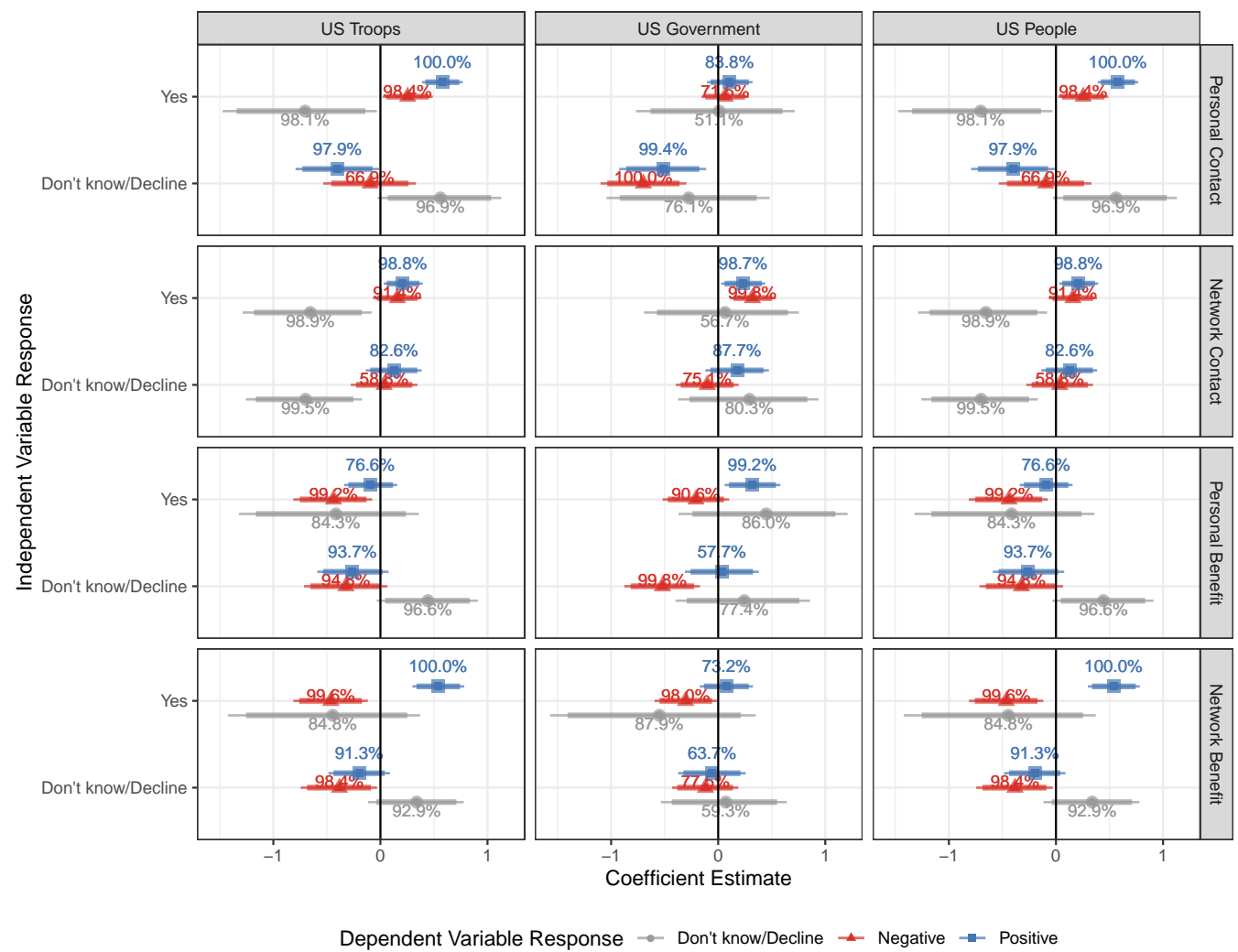

Figure 4: Coefficient plot of the results from Tables 1, 2, and 3. 90\% and 95\% credible intervals shown. Percentage values show the percent of the overall coefficient distribution that falls above or below 0 .

correlation between network contacts and negative attitudes, with $\geq 90 \%$ of the coefficient distributions falling above 0 . As with direct contact, network contacts appear to increase the probability of both positive and negative responses. Unlike the direct contact variable, we also see positive coefficients when individuals are asked about the U.S. government. Again, knowing someone who has had contact with U.S. military personnel seems to move people away from the "Neutral" category and decreases the probability that individuals respond "I don't know/Decline to answer." Overall, the magnitude of these coefficients is fairly small compared with the positive coefficients we see for direct contact.

Individuals who report having received a direct economic benefit from the U.S. military presence are more likely to express a positive attitude towards the U.S. government, but this 
does not correlate strongly with a shift in positive attitudes towards either the U.S. people or the U.S. military. In these cases $75-99 \%$ of the coefficient distributions fall below 0 , contrary to our expectations. Personally receiving an economic benefit from the U.S. military does appear to correlate with a reduced probability of a negative response. Across all three models/groups we see $\geq 90 \%$ of the coefficient distributions falling below 0 . These results suggest that individuals deriving personal economic benefits from a U.S. military presence are less likely to express negative attitudes towards other U.S. actors, but are only more likely to express positive assessments of the U.S. government.

Last, knowing someone who received an economic benefit correlates with an increase in the probability of expressing a positive assessment of the U.S. people and military presence within a state, but does not correlate with more positive attitudes towards the U.S. government. The magnitude of these coefficients is relatively large compared to the others, and is similar in size to the personal contact variable. We also find that network benefits correlate with a lower probability of a negative response across all three groups. In the case of the troops and people models this effect is fairly large by comparison, equating to an approximate $13 \%$ reduction in the probability of a negative response.

That the coefficient for network benefits is larger than for direct benefits may seem counterintuitive, but it is consistent with existing work on the contact hypothesis. Indirect benefits may lead to greater harmony across groups because indirect interactions are unlikely to have the negative side effect of provoking the anxiety that sometimes accompanies interactions with outgroups. It is easier to generalize positively from an indirect benefit because the benefit is attributed to the outgroup as a whole as opposed to the outgroup individual involved in the interaction (Paolini et al. 2004).

Figure 5 provides information about the distribution of the model's estimates of varying intercepts. Panel A shows the population-level intercepts for the three outcome variables and the three response equations associated with each. Panel B shows country-level error 
A

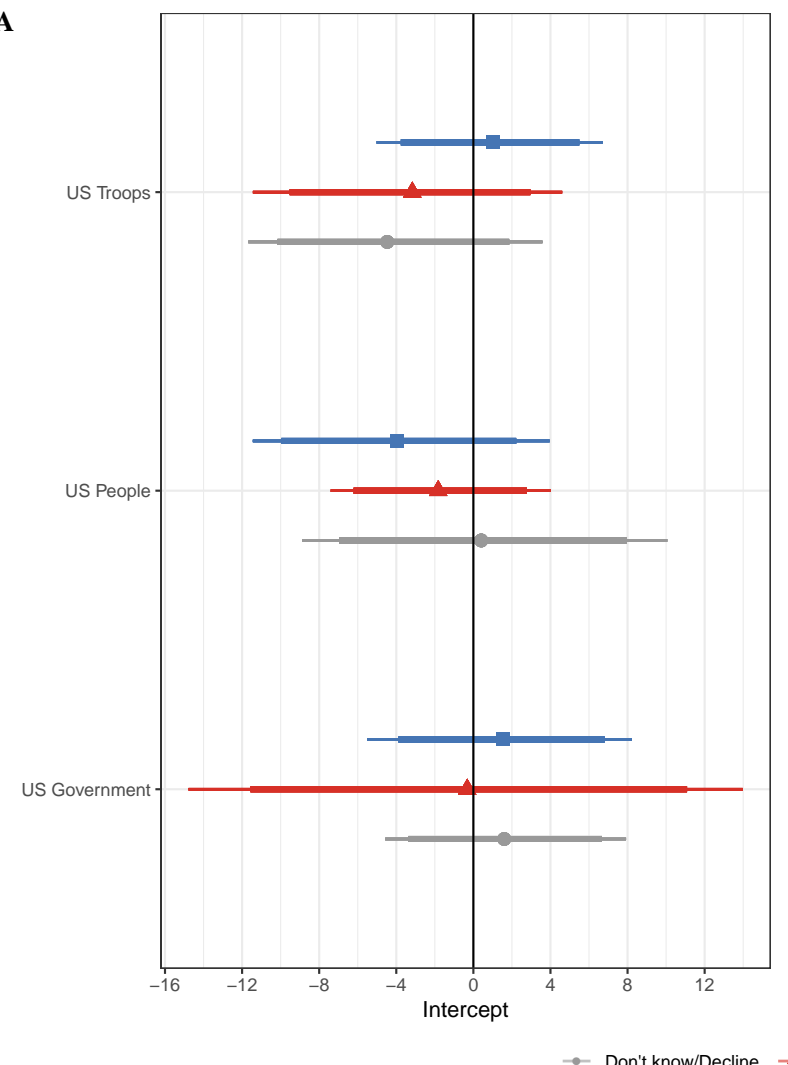

- Don't know/Decline $\_$Negative $\rightarrow$ Positive
B

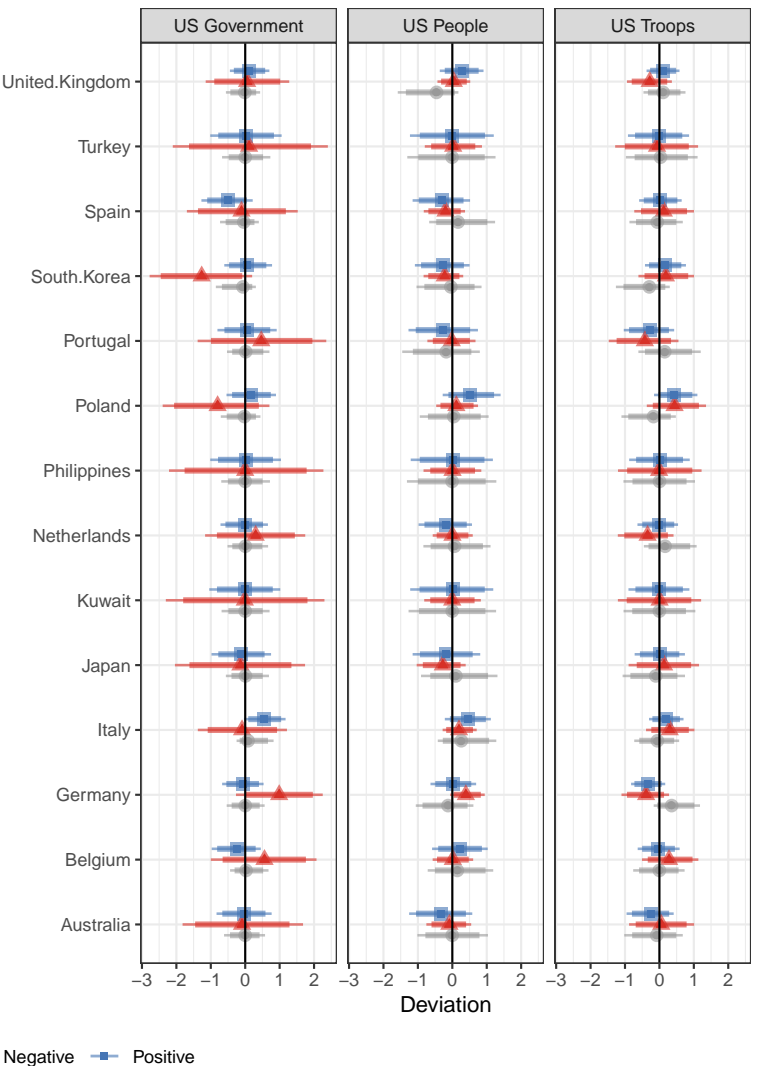

Figure 5: Predicted population-level intercepts (Panel A) and predicted country-level error (Panel B) from models shown in Tables 1, 2, and 3. $90 \%$ and $95 \%$ credible intervals shown.

for each model/group and response. In Panel A we can see that the baseline probability of receiving a positive evaluation of the U.S. military presence across all countries is slightly higher than the baseline probability of a negative evaluation, though there is overlap in the distributions. For the U.S. people estimates we find that the median population-level intercept is slightly lower for positive evaluations as compared to negative, but we again see overlap between the distributions. For the U.S. government model we find that the median intercept values are roughly equivalent, but the distribution of the negative equation intercept is substantially larger than either of the other equations. This suggests that the baseline probability of receiving a negative evaluation of the U.S. government varies considerably more across countries as compared to other evaluation categories for the other groups of interest. 
This is an author-produced, peer-reviewed version of this article. The final, definitive version of this document can be found online at American Political Science Review, published by Cambridge University Press. Copyright restrictions may apply. doi: 10.1017/S0003055419000868

This matches the basic descriptive statistics - the rate of negative evaluations varies more across countries than positive evaluations.

Panel B shows the median country-level error and corresponding credible intervals. Overall, we do not typically observe large country-level error values. South Korea and Poland stand out as having a relatively low baseline for negative evaluations of the U.S. government, as compared to other countries. Conversely, Germany has a relatively high baseline for these negative attitudes. We generally observe greater dispersion in the negative attitude error values for the U.S. government model as compared to the other groups/models. When looking at the U.S. troops model we can see that some countries, like Portugal and Germany, have lower baselines for both positive and negative attitudes towards U.S. personnel stationed within their borders. In other cases, like Poland and South Korea, we see slightly higher baselines for "informed opinions" towards U.S. personnel. Overall, our findings reflect varying attitudes towards the U.S. government, particularly when compared to other U.S. actors, and respondents drawing distinctions between these different groups.

\section{A Note on Selection Bias}

In evaluating the contact hypotheses, it is important to take into account that those who choose to interact with members of an outgroup are often the individuals who hold the least amount of prejudice (Pettigrew 1998). Those individuals who have had contact with members of the American military may have selected themselves into that situation because they already held more positive views of the U.S., whereas those with negative views regarding the U.S. may choose to avoid these interactions. If this were the case then this would bias our results.

While this is a possibility, our qualitative interviews suggest that a large variety of people interact with the U.S. military. For example, it is often those with the largest grievances who select themselves into (negative) personal interactions with members of the U.S. military. 
A U.S. government relations officer at a military base in Germany noted that it is not uncommon for bar fights to break out between members of the U.S. military and foreign nationals who approach the Americans with grievances regarding U.S. military interventions abroad (Government Relations Officer Interview 2019). In addition, some of the settings in which locals may interact with Americans, like town hall meetings that are attended by representatives from the U.S. military, are often ones in which locals choose because they have grievances against the Americans. A member of the Lakenheath Parish Council in England noted that whenever there are any issues related to the nearby U.S. Air Force base, the local Air Commander will attend a parish council meeting. Thus, the people with grievances will select themselves into this interaction not because they have positive views of the Americans, but because they have a grievance (Interview with Local Council Member \#1 2019).

In addition, many of the military installations are located near smaller towns where there is a limited number of businesses that both locals and members of the U.S. military can frequent, making interactions more likely regardless of people's preferences. For example, Lakenheath, England is a village with a population of less than 5,000. While there are certainly businesses that market themselves as U.S.-friendly (for example, by putting U.S. flag stickers on their doors), there are also other businesses, such as supermarkets, that tend to be visited by most members of the population (Public Affairs Officer Interview 2019). Given limited economic opportunities, it can be difficult for people to relocate to another town even if they dislike the American military presence. One of the constant themes we observed in our interviews in both England and Germany was that locals were bothered by the sound of military aircraft, though it seems notable that despite this being a problem, people were still willing to live in the area.

Our use of the choice model alleviates this problem to a certain extent, though not completely. When considering these selection issues, ordered or binary measures of respondent 
attitudes (e.g. Positive/Not Positive) would mask the fact that contact can generate variation between various non-positive categories. For example, we find that contact often correlates with a higher probability of positive and negative attitudes, but a reduction in the probability of receiving an "Don’t know/Decline to answer" response. ${ }^{14}$ Even where we observe both positive and negative views increasing, the correlations are often not symmetric-with personal contact, for example, the coefficient for contact in the positive equation is larger than in the negative equation.

In accordance with contact hypothesis literature, we believe that a positive network effect is evidence that this relationship is not driven solely by a selection effect (Wright et al. 1997; Paolini et al. 2004). While individuals who hold more pro-American views may be more willing and likely to interact with members of the U.S. military in either personal or business relations, they are unlikely to be able to control whether people in their social network interact with the Americans. Thus, observing a positive correlation between network contact and positive attitudes is evidence against the relationship being caused by selection bias. Though we need to do more to establish that contact and/or benefits can actually bring about a causal change in individuals' views, this research suggests that individuals with pre-existing positive attitudes towards the U.S. military are not the only ones selecting into interactions with them.

\section{Conclusions}

This research marks the first of its kind in studying mass attitudes towards the U.S. military deployments in their host countries. Surveying over 14,000 people across 14 countries, we find important trends with implications for both foreign policy-making and international

\footnotetext{
${ }^{14}$ This fits with findings by Goldsmith and Horiuchi (2009) who find that high-level official visits, as an act of public diplomacy, can exacerbate negative perceptions of the U.S. when the U.S. is engaging in unpopular foreign policy.
} 
relations theory. We argue that U.S. leadership during the post-War era relied not only on government policies, but also on the acceptance of foreign populations. The U.S. military, traditionally considered an instrument of hard power, also plays a part in building soft power and influencing perceptions of U.S. actors. Our results suggest that contact with members of the U.S. military may reduce prejudice against U.S. actors and build more positive perceptions of them. This relationship exists even when taking into account the effect of economic benefits.

Interpersonal contact may increase both positive and negative views. Intuitively this finding makes sense - media and historical accounts of the U.S. military's presence in other countries are full of stories of social ills, including crime, environmental degradation, and more. Our findings also indicate that these negative accounts may suffer from selection bias, and, in line with contact theory, show that interactions with U.S. military personnel correlate with more positive attitudes of U.S. actors. Alternatively, the economic benefits that flow from the U.S. military presence in a state correlate with a reduced probability that individuals express negative views of various U.S. actors, while in some cases also correlating with a higher probability that individuals express positive views.

This work represents an important contribution to international relations theory and our understanding of the microfoundations of U.S. leadership and the domestic underpinnings of hierarchical and contractual security relationships. In particular, our results suggest that U.S. military deployments may help build support for the U.S. government and its policies through the transfer of economic resources. Governments and leaders may have slack when negotiating away sovereignty to the U.S. in various areas of foreign policy, but that slack may be substantially reduced when foreign publics hold more negative views of the U.S. and its agents. This analysis represents a critical step insofar as it establishes the correlates of mass attitudes towards U.S. military deployments, but more work is required to better understand how, and when, such attitudes translate into actual pressure on government 
officials. Large, long-term military deployments represent significant investments by both the U.S. and host-country, and these considerations must be balanced against host politicians' short-term political realities and the likelihood that initially narrow public grievances may develop into something greater.

These findings also have substantive policy implications. Given the centrality of global military deployments to U.S. foreign policy, understanding mass attitudes towards those deployments can aid policymakers in better understanding the sources of support and opposition foreign leaders face among their publics when dealing with the U.S. Fostering positive perceptions of its military personnel could allow the U.S. government to more easily establish favorable basing and status of force agreements with foreign states. Cooley and Nexon (2013) note that the U.S. basing network exists due to common security interests and shared values. Where those interests and values are viewed as lacking, host governments may be more resistant to U.S. wishes. One strategy that the U.S. has pursued is to create stakeholders that go beyond the government. Thus, promoting more positive views of the U.S. among foreign publics may contribute to the creation of favorable agreements. These results stand in contrast with Goldsmith and Horiuchi $(2009,872)$ who find that high-level U.S. efforts at public diplomacy are not effective at countering negative images and news coverage. Our results suggest that lower-level and "unintended" efforts at public diplomacy may yield different results.

At present no other state rivals the United States in size and scope of its overseas military presence. As other countries like China begin to expand their military influence abroad they will likely have to deal with many of the same concerns as the United States. Until now, members of the general public in states where the U.S. has had a military presence view China as having economic, not military interests (Interview with Panamanian Journalist 2018). This is likely to change as China expands its global military footprint. As one British Member of Parliament noted during our interviews, regarding British inaction with respect 
to the Chinese taking control of the port of Piraeus in Greece, "Are we mad? How stupid do we have to be?" (Interview with British Member of Parliament \#1 2019). Countries like Djibouti, which hosts military forces from the U.S., China, France, Germany, Italy, Spain, and Japan, provide interesting early opportunities for examining how mass attitudes towards foreign military deployments vary by sender country.

Future research should focus on better evaluating the causal relationship between various forms of contact and benefits and opinion formation. Researchers should also look to better understand how different types of events and interactions serve to condition the possible causal effects of interpersonal contact and economic benefits. It is possible that some events often associated with a U.S. military presence, like crime, support for ongoing military operations, or the disruption of normal social or economic activities, may condition the relationships we find. If so, future research should analyze how strong and/or long-lasting, such conditioning effects may be. High-profile negative events or unpopular policy changes can provide openings for domestic opposition to the U.S. presence. For example, a German peace activist we interviewed noted that having U.S. drones based in Germany increased anti-base sentiment (Interview with German Peace Activist 2019). Thus, to truly reap the cooperative benefits of public diplomacy by the military, the U.S. should focus on reducing the incidence of negative events. 


\section{References}

Allen, Michael A and Michael E Flynn. 2013. "Putting Our Best Boots Forward: US Military Deployments and Host-country Crime." Conflict Management and Peace Science 30(3):263-285.

Allen, Michael A, Michael E Flynn and Julie VanDusky-Allen. 2017. "Regions of Hierarchy and Security: US Troop Deployments, Spatial Relations, and Defense Burdens." International Interactions 43(3):397-423.

Atkinson, Carol. 2014. Military Soft Power: Public Diplomacy Through Military Educational Exchanges. Lanham: Rowman \& Littlefield.

Bell, Sam R, K Chad Clay and Carla Martinez Machain. 2017. "The Effect of US Troop Deployments on Human Rights." Journal of Conflict Resolution 61(10):2020-2042.

Biglaiser, Glen and Karl DeRouen Jr. 2009. "The Interdependence of US Troop Deployments and Trade in the Developing World." Foreign Policy Analysis 5(3):247-263.

Böhnke, Jan Rasmus and Christoph Zürcher. 2013. "Aid, Minds and Hearts: The Impact of Aid in Conflict Zones." Conflict Management and Peace Science 30(5):411-432.

Braithwaite, Alex and Jeffrey Kucik. 2017. "Does the Presence of Foreign Troops Affect Stability in the Host Country?" Foreign Policy Analysis 14(1):536-560.

Bueno de Mesquita, Bruce, Alastair Smith, James D Morrow and Randolph M Siverson. 2005. The Logic of Political Survival. Cambridge: MIT press.

Calder, K E. 2007. Embattled Garrisons: Comparative Base Politics and American Globalism. Princeton: Princeton University Press. 
Chanlett-Avery, Emma and Ian E Rinehart. 2012. The US military presence in Okinawa and the Futenma base controversy. Technical report Congressional Research Service.

Cooley, Alexander. 2008. Base politics: Democratic change and the US military overseas. Ithaca: Cornell University Press.

Cooley, Alexander and Daniel H Nexon. 2013. "“The Empire Will Compensate You": The Structural Dynamics of the US Overseas Basing Network." Perspectives on Politics 11(4):1034-1050.

Cull, Nicholas John. 2008. The Cold War and the United States Information Agency: American Propaganda and Public Diplomacy, 1945-1989. Cambridge: Cambridge University Press.

Davis, Sasha. 2011. "The US Military Base Network and Contemporary Colonialism: Power Projection, Resistance and the Quest for Operational Unilateralism." Political Geography $30(4): 215-224$.

Defense Manpower Data Center. 2019. Number of Military and DoD Appropriated Fund (APF) Civilian Personnel Permanently Assigned. Technical report U.S. Department of Defense.

Finnemore, Martha. 1996. "Norms, Culture, and World Politics: Insights from Sociology's Institutionalism." International organization 50(2):325-347.

Flynn, Michael, Carla Martinez Machain and Alissandra Stoyan. 2019. "Building Trust: The Effect of U.S. Development-oriented Troop Deployments on Public Opinion in Peru." International Studies Quarterly 63(3):742-755.

Fordham, Benjamin O and Katja B Kleinberg. 2011. "International Trade and US Relations with China." Foreign Policy Analysis 7(3):217-236. 
Goldsmith, Benjamin E and Yusaku Horiuchi. 2009. "Spinning the Globe? US Public Diplomacy and Foreign Public Opinion." The Journal of Politics 71(3):863-875.

Goldsmith, Benjamin E, Yusaku Horiuchi and Terence Wood. 2014. "Doing Well by Doing Good: The Impact of Foreign Aid on Foreign Public Opinion." Quarterly Journal of Political Science 9:87-114.

Gouldner, Alvin. 1979. The Future of Intellectuals and the Rise of the New Class. New York: Macmillan.

Government Relations Officer Interview. 2019. "Interview with Government Relations Officer at Clay Kaserne Army Base in Wiesbadenm, Germany, 2019-07-25.”.

Harkavy, Robert E. 1989. Bases Abroad: The Global Foreign Military Presence. Stockholm: SIPRI.

Heo, Uk and Min Ye. 2017. "U.S. Military Deployment and Host-nation Economic Growth." Armed Forces \&3 Society 45(2):234-267.

URL: http://journals.sagepub.com/doi/10.1177/0095327X17738219

Holmes, Amy Austin. 2014. Social Unrest and American Military Bases in Turkey and Germany since 1945. New York: Cambridge University Press.

Huckfeldt, Robert. 2001. "The Social Communication of Political Expertise." American Journal of Political Science pp. 425-438.

Hudson, Valerie M. 2005. "Foreign policy analysis: actor-specific theory and the ground of international relations." Foreign policy analysis 1(1):1-30.

Hudson, Valerie M and Patricia Leidl. 2015. The Hillary Doctrine: Sex and American Foreign Policy. New York: Columbia University Press. 
Ikenberry, G John. 2004. "Liberalism and Empire: Logics of Order in the American Unipolar Age." Review of International Studies 30(4):609-630.

Ikenberry, G John. 2011. Liberal Leviathan: The Origins, Crisis, and Transformation of the American World Order. Princeton: Princeton: Princeton University Press.

Institute for International Education. 2018. Host Regions and Destinations of U.S. Study Abroad Students. Technical report Open Doors Report on International Educational Exchange.

URL: $\quad$ https://www.iie.org/Research-and-Insights/Open-Doors/Data/US-StudyAbroad/Destinations

International Monetary Fund. 2018. Direction of Trade Statistics. Technical report International Monetary Fund.

URL: http://data.imf.org/?sk=9D6028D4-F14A-464C-A2F2-59B2CD424B85

Interview with British Member of Parliament \#1. 2019. "Interview with British Labour Member of Parliament in London, 2019-07-17.”.

Interview with Embassy Staff. 2018. "Interview with US Embassy Intern in Panama, 201807-12.”.

Interview with Embassy Staff \#4. 2018. "Interview with US Embassy Staff in Peru \#4, 2018-07-19.".

Interview with former President. 2018. "Interview with former Panamanian President, 201807-14.".

Interview with German Peace Activist. 2019. "Interview with German Peace Activist in Berlin, 2019-07-23.". 
Interview with Local Council Member \#1. 2019. "Interview with Local Council Member in Lakenheath, England, 2019-07-18.”.

Interview with Panamanian Journalist. 2018. "Interview with Panamanian Journalist, 201807-13.".

Interview with Panamanian Journalist and Former Government Official. 2018. "Interview with Former Panamanian High-ranking Government Official and Journalist, 2018-07-12.”.

Interview with Peruvian journalist. 2018. "Interview with Peruvian Journalist, 2018-07-18.".

Jennings, M. Kent, Laura Stoker and Jake Bowers. 2009. "Politics Across Generations: Family Transmission Reexamined." The Journal of Politics 71(3):782-799.

Jones, Garett and Tim Kane. 2012. "Us Troops and Foreign Economic Growth." Defence and Peace Economics 23(3):225-249.

Kleinberg, Katja B. and Benjamin O. Fordham. 2018. "Don’t Know Much about Foreign Policy: Assessing the Impact of "Don't Know" And "No Opinion" Responses on Inferences about Foreign Policy Attitudes." Foreign Policy Analysis 14(3):429-448.

Lake, David A. 2009a. Hierarchy in International Relations. Ithaca: Cornell University Press.

Lake, David A. 2009b. "Regional Hierarchy: Authority and Local International Order." Review of International Studies 35(S1):35-58.

Lake, David A. 2013. "Legitimating Power: The Domestic Politics of US International Hierarchy." International Security 38(2):74-111.

Leeds, Brett Ashley and Burcu Savun. 2007. "Terminating Alliances: Why Do States abrogate agreements?" The Journal of Politics 69(4):1118-1132. 
Leeds, Brett Ashley, Jeffrey M Ritter, Sara McLaughlin Mitchell and Andrew G Long. 2002. "Alliance Treaty Obligations and Provisions, 1815-1944." International Interactions $28(3): 237-260$.

Levine, Jeffrey. 2005. Choosing Alone? The Social Network Basis of Modern Political Choice. In The Social Logic of Politics, ed. Alan S. Zuckerman. Philadelphia, PA: Temple University Press Philadelphia chapter 7, pp. 132-151.

Liebkind, Karmela and Alfred L McAlister. 1999. "Extended Contact Through Peer Modelling to Promote Tolerance in Finland." European Journal of Social Psychology 29(5$6): 765-780$.

Marshall, Monty G, Keith Jaggers and Ted Robert Gurr. 2011. "Polity IV Project: Political Regime Characteristics and Transitions, 1800-2010.”.

URL: http://www.systemicpeace.org/polity/polity4.htm

Martinez Machain, Carla and T Clifton Morgan. 2013. "The Effect of US Troop Deployment on Host States' Foreign Policy." Armed Forces 8 Society 39(1):102-123.

McClurg, Scott D. 2006. "The Electoral Relevance of Political Talk: Examining Disagreement and Expertise Effects in Social Networks on Political Participation." American Journal of Political Science 50(3):737-754.

McGillivray, Fiona and Alastair Smith. 2018. Punishing the Prince: A Theory of Interstate Relations, Political Institutions, and Leader Change. Princeton: Princeton University Press.

Melissen, Jan. 2005. The New Public Diplomacy: Between Theory and Practice. In The New Public Diplomacy: Soft Power in International Relations, ed. Jan Melissen. Springer pp. 3-27. 
Milner, Helen V and Dustin Tingley. 2013. "Public opinion and foreign aid: A review essay." International Interactions 39(3):389-401.

Moon, Katharine HS. 1997. Sex among Allies: Military Prostitution in Us-korea Relations. New York: Columbia University Press.

Nelson, Daniel J. 1987. Defenders or Intruders? The Dilemmas of US Forces in Germany. Boulder: Westview Press.

Nieman, Mark David. 2016. "The Return on Social Bonds: Social Hierarchy and International Conflict." Journal of Peace Research 53(5):665-679.

Nisbet, Erik C, Matthew C Nisbet, Dietram A Scheufele and James E Shanahan. 2004. "Public Diplomacy, Television News, and Muslim Opinion." Harvard International Journal of Press/Politics 9(2):11-37.

Nye, Joseph S. 2004. Soft power: The means to success in world politics. New York: Public affairs.

Office of the Under Secretary of Defense (Comptroller) / Chief Financial Officer. Various Years. Operation and Maintenance Overview Budget Estimates. Technical report U.S. Department of Defense.

Paolini, Stefania, Miles Hewstone, Ed Cairns and Alberto Voci. 2004. "Effects of Direct and Indirect Cross-group Friendships on Judgments of Catholics and Protestants in Northern Ireland: The Mediating Role of an Anxiety-reduction Mechanism." Personality and Social Psychology Bulletin 30(6):770-786.

Pettigrew, Thomas F. 1998. "Intergroup Contact Theory." Annual Review of Psychology $49(1): 65-85$. 
Pettigrew, Thomas F, Oliver Christ, Ulrich Wagner and Jost Stellmacher. 2007. "Direct and Indirect Intergroup Contact Effects on Prejudice: A Normative Interpretation." International Journal of Intercultural Relations 31(4):411-425.

Pew Research Center. 2016. "A Wider Ideological Gap Between More and Less Educated Adults.".

URL: $\quad$ http://www.people-press.org/2016/04/26/a-wider-ideological-gap-between-moreand-less-educated-adults/

Posen, Barry R. 2014. Restraint: A New Foundation for US Grand Strategy. Ithaca: Cornell University Press.

Public Affairs Officer Interview. 2018. "Interview with US Embassy Public Affairs Officer in Panama, 2018-07-12.".

Public Affairs Officer Interview. 2019. "Interview with Public Affairs Officer at Clay Kaserne Army Base in Wiesbadenm, Germany, 2019-07-25.".

Putnam, Robert. 2001. "Social Capital: Measurement and Consequences." Canadian Journal of Policy Research 2(1):41-51.

Putnam, Robert D. 1988. "Diplomacy and domestic politics: the logic of two-level games." International organization 42(3):427-460.

Reveron, Derek S. 2010. Exporting Security: International Engagement, Security Cooperation, and the Changing Face of the US Military. Washington, D.C.: Georgetown University Press.

Simbulan, Roland G. 2009. "People's Movement: Responses to Evolving US Military Activities in the Philippines." The Bases of Empire: The Global Struggle Against US Military Posts p. 145. 
Stockholm International Peace Research Institite (SIPRI). 2019. "SIPRI Military Expenditure Database." Online.

URL: https://www.sipri.org/databases/milex

Tokdemir, Efe. 2017. "Winning Hearts \& Minds (!) The Dilemma of Foreign Aid in AntiAmericanism." Journal of Peace Research 54(6):819-832.

United States Department of Defense. Various Years. Military Construction, Family Housing, and Base Realignment and Closure Program (C-1). Technical report U.S. Department of Defense Office of the Under Secretary of Defense (Comptroller).

Vine, David. 2015. Base Nation: How U.S. Military Bases Abroad Harm America and the World. New York: Metropolitan Books/Henry Holt.

Voeten, Erik, Anton Strezhnev and Michael Bailey. 2009. "United Nations General Assembly Voting Data.".

URL: https://dataverse.harvard.edu/dataset.xhtml?persistentId=doi:10.7910/DVN/LEJUQZ

Wohlforth, William C. 1999. "The Stability of a Unipolar World." International Security $24(1): 5-41$.

Woolcock, Michael and Deepa Narayan. 2000. "Social Capital: Implications for Development Theory, Research, and Policy." The World Bank Research Observer 15(2):225-249.

World Bank. 2018. "World Development Indicators.".

URL: https://datacatalog.worldbank.org/dataset/world-development-indicators

Wright, Stephen C, Arthur Aron, Tracy McLaughlin-Volpe and Stacy A Ropp. 1997. "The Extended Contact Effect: Knowledge of Cross-group Friendships and Prejudice." Journal of Personality and Social Psychology 73(1):73-90. 
This is an author-produced, peer-reviewed version of this article. The final, definitive version of this document can be found online at American

Political Science Review, published by Cambridge University Press. Copyright restrictions may apply. doi: 10.1017/S0003055419000868

Zuckerman, Alan S. 2005. The Social Logic of Politics: Personal Networks as Contexts for Political Behavior. Philadelphia: Temple University Press. 